\title{
DIGITAL ECONOMY AS A FACTOR IN THE DEVELOPMENT OF A SOCIAL STATE
}

\author{
Alla Silenko ${ }^{1}$, Vira Bezrodna ${ }^{2}$, Olga Nikogosyan ${ }^{3}$
}

\begin{abstract}
The digital economy is becoming a development trend in most modern countries, the basis for sustainable economic growth and living standards of the population. In this regard, it seems relevant to consider the significance of the impact of the digital economy on the welfare state. The purpose of the article is to study the influence of the digital economy on the quality and living conditions of citizens in a welfare state. Methodology. The study is based on a systemic approach, within which the digital economy has been viewed as an external phenomenon (input) that has been able to affect the welfare state system (output). Results. The hypothesis of the study that the digital economy improves the quality and living conditions of citizens in a welfare state was partially confirmed. However, it became clear that in addition to positive, the digital economy has negative consequences for people. For example, the digital economy improves the ability to solve many social problems, but at the same time creates new problems. For example, it creates new jobs, new professions, as a result of which workers in traditional professions become unclaimed. The digital economy not only solves and creates problems, but also exposes them. So, it has clearly outlined the problem of social inequality in Ukraine. Undoubtedly, the digitalization of public social services makes life easier for people, but only if they are prepared for this process. Digital illiteracy of the population, characteristic of countries lagging behind in technological development, including Ukraine, is an obstacle to the introduction of digitalization into the social sphere. At the same time, the state is not ready for the active introduction of digital technologies into the system of social policy yet due to the lack of necessary resources. Digitalization will not improve people's lives until the state has funds for social policy. And yet, some measures are being taken in this direction.
\end{abstract}

Key words: digital economy, welfare state, information and communication technologies, social risks, benefits of digitalization.

JEL Classification: $\mathrm{O33}, \mathrm{O} 35$

\section{Introduction}

The digital economy is becoming a development trend in most modern countries, the basis for sustainable economic growth and living standards of the population. In this regard, it seems relevant to consider the significance of the impact of the digital economy on the welfare state. The study of this problem, in addition to its theoretical relevance, is of great practical importance, since in fact we are talking about the real provision of such rights and freedoms of Ukrainian citizens as the right to privacy of communication, the right to movement, freedom of speech and information, the right to privacy. For example, the introduction of a face recognition system became a direct threat to the latter.

The purpose of the article is to study the impact of the digital economy on the quality and living conditions of citizens in a welfare state. To achieve this goal, it is necessary to solve the following tasks: to determine the degree of development of the problem; to analyze social achievements and risks of the digital economy; to consider the technologies of the digital economy that are used in the social state of Ukraine.

The hypothesis of the study is that the digital economy improves the quality and living conditions of citizens in a social state, because economic growth

\footnotetext{
Corresponding author:

${ }^{1}$ Odessa State Environment University, Ukraine.

E-mail: Allamaksim74@gmail.com

ORCID: https://orcid.org/0000-0001-9420-0019

${ }^{2}$ O.S. Popov Odessa National Academy of Telecommunications, Ukraine.

E-mail: verabezrodnaya@gmail.com

ORCID: https://orcid.org/0000-0002-5602-1930

${ }^{3}$ Odesa I.I. Mechnikov National University, Ukraine.

E-mail: olyanicogosyan@onu.edu.ua

ORCID: https://orcid.org/0000-0001-9114-2271
} 
is a condition for social development. And the digital economy, largely due to the IT sector, is growing much faster than the traditional economy. Thus, the volume of information and communication technologies (ICT) in the European economy is $5 \%$. Half of all productivity growth in Europe is investment in ICT (Abeliansky and Hilbert, 2017). Thus, the process of solving social problems receives a new impetus.

\section{The degree of development of the problems of the welfare state and the digital economy}

Over the past 20 years, a lot of studies by Ukrainian scientists have appeared on various aspects of the development of the social state, "which guarantees all people the realization of their rights and freedoms, equal conditions for the free development of an individual, social protection for those in need, achieving social and political stability by peaceful means and interests of all members of society" (Silenko, 2000). Scientists have studied the socio-political factors of the welfare state (Silenko, 2000), the role of civil society in the formation of the welfare state, the welfare state model (Khoma, 2012), the problems of the influence of globalization, political modernization on the welfare state (Shulzhenko, 2007) and many others.

At the same time, the issues of the impact of digitalization on socio-economic processes have not been sufficiently considered yet. This is due to the fact that the digital economy, which, in the full sense of the word, can change the world, was first discussed in the 90 s of the 20th century. It was about a phenomenon that was rapidly penetrating into all spheres of human life. It was then that the first concepts of the digital economy began to appear. In particular, the concept of the Internet economy by American economists J.K. McKie-Mason and H. Varian, as well as L.W. McKnight appeared. In their view, the Internet economy is the economy of the Internet services (Kupchishina, 2018).

For objective reasons, the benefits of the digital economy reached Ukraine like other post-communist countries more slowly than the economically developed countries. Therefore, we can say that research on the digital economy in Ukraine is at an early stage. In addition, the digital economy is mainly the subject of research by economists. Thus, the formation of the information economy is studied by A. Maslov (Maslov, 2012). The priority directions of the digital economy development in Ukraine are studied by S. Veretiuk and V. Pilinskyi (Veretiuk, Pilinskyi, 2016). Digital modernization of the Ukrainian economy as an opportunity for breakthrough development is studied by V. Liashenko and O. Vyshnevskyi (Liashenko, Vyshnevskyi, 2018). Theoretical aspects of the digital economy are studied by L. Matveichuk (Matveichuk, 2018) and others. At the same time, there are practically no studies of the socio-political problems of the digital economy. This explains our interest in this topic. In the post-Soviet space, the problems of digital transformation of socio-economic systems are studied by Iu. Gribanov (Gribanov, 2019). The education and development of the educational services market is considered by E. Peshchannikova (Peshchannikova, 2019). The socio-economic aspects of regional development in the digital economy are analyzed in the dissertation work by V. Vilken (Vilken, 2020).

The concept of "digital economy" was introduced into scientific circulation not so long ago. In 1995, the American scientist Nicholas Negroponte first used it during a conversation with colleagues about the advantages of the new economic system over the previous one.

At the political level, the phenomenon of the digital economy was first discussed at the G20 summit in Antalya in 2015. The G20 leaders recognized that the digital economy included both positive and negative factors influencing global growth. They launched the G20 Development and Cooperation Initiative in the digital economy since 2016 (G20 Programma po razvitiiu ...)

In April 2017, the first meeting of G20 ministers was held, which adopted the "Ministerial Declaration on the Digital Economy of the G20" (Konferentciia G20). It was planned that by 2025 all citizens of these countries would be connected to digital communications.

Today, the digital economy is discussed by officials and experts, economists and politicians, representatives of the technical and humanitarian professions, businessmen and students. But, as practice shows, they all put different meanings into this concept; for IT workers, this is artificial intelligence, robotization, drones, etc. For businessmen, the digital economy is an "on-demand economy", that is, consumer-oriented. For physicians, this is telemedicine, which allows them to receive medical services regardless of the time and location of the patient. For civil servants, this is an e-government system. For ordinary citizens, these are electronic salary and pension payment cards, online payments for services and goods, an electronic queue, etc.

In our opinion, the meaning of the content of the digital economy is conveyed most fully by the definition of H. Karcheva and others, according to which the digital economy is "an innovative dynamic economy, which is based on the active implementation of innovations, and information and communication technologies in all types of economic activities and spheres of life of society, which allows to increase the efficiency and competitiveness of individual companies in the economy and the standard of living of the population" (Karcheva, Ohorodnia, Openko, 2017). 


\section{Social achievements and risks of the digital economy}

The scientific discussions about the dangers and benefits of the Internet have not been completed yet, and disputes about the dangers and benefits of the digital economy are flaring up in the scientific literature. This is not surprising, because everything has its pluses and minuses, and the digital economy is no exception in this sense. The digital economy is a "train that cannot be stopped"; therefore, the tasks of a modern state are, on the one hand, to minimize the risks of digitalization and, on the other hand, to maximize its positive impact on socio-economic development

N. Romanova points to the most important consequences of the digitalization of the social sphere, such as the growth in the volume of information aimed at the social sphere. It is not only about the spheres of distribution, exchange and consumption of vital goods and services, but also about the social aspects of economic activity, social and spiritual relations that contribute to the formation of human potential; the impact of the digital environment on raising the cultural level of the population (online access to the repositories of museums, library funds, etc.); the growth of the level of digital inequality, elitism of knowledge, the essence of which is that access to knowledge is gained mainly by the elite strata of society; the emergence of new and the disappearance of existing professions (Romanova, 2020).

Olha Pishchulina, a leading expert on social and gender programs at the Razumkov Center, rightly notes that «the impact of digitalization on society and the economy is ambiguous: on the one hand, the economy is developing at a new level of interaction of all its elements, on the other, the old system of production and distribution of goods is being destroyed. In this sense, it is no coincidence that digital technologies are characterized as "disruptive" $\gg$ (Dvi storony tsyfrovykh tekhnolohii...).

The digital economy is also transforming such a phenomenon as social inequality, which, in the context of the formation of the information society, has acquired new forms, in particular, information inequality. After all, the benefits of the digital economy cannot be used by people with low incomes, insufficient education, and physical disabilities. This puts them in an unequal position compared to those who can afford to use digital technology to the fullest. Also, social inequality is exacerbated by regional differences. In richer regions, people have more income, and thus digital opportunities, than in poor regions. At the same time, information inequality exacerbates social inequality even more. We agree with the researchers who point out that the benefits of the digital economy are unevenly distributed. What is progress for some countries is a threat to development for others. It is already obvious that the digital economy is undermining the foundations of a traditional society, a welfare state. Traditional jobs are shrinking, wages are changing, the digital divide is widening, personal security threats are increasing, and much more.

So, on the one hand, the digital economy provides a technological basis for socio-economic development, on the other hand, it reformats the structure of human capital. Those professions that seemed fantastic yesterday are becoming commonplace today; those professions that seemed eternal yesterday disappear from the labor market today. Of course, this primarily applies to technologically advanced countries. For example, the profession of a driver is under threat of extinction in those countries where robotization of road transport is highly developed and in the not too distant future technical problems of auto-driving a car will be solved. Several years ago, specialists of the State Employment Service of Ukraine, the authors of the Atlas of New Professions in Ukraine, predicted the disappearance of some professions after 2020, namely conductors, postmen, information bureau operators, cashiers, travel managers, translators, accountants and others (Konovalova, Svetlevskaia, 2017). Here the professions of the future are also indicated: a drone operator, in the medical field - a nanomedicine, bioethics, genetic consultant and others.

Indeed, today, in 2020, it can be stated that not all, but some of their predictions have come true. So the passenger traffic today is controlled with the help of e-tickets, the purchase of products is carried out through self-service cash desks, a taxi can be called via the Internet.

However, due to the technological backwardness of Ukraine, not all forecasts have come true. In addition, experts cite cheap labor as another reason. If in developed digital economies robotization is being introduced in order to achieve a lower cost of production, then in Ukraine the low cost of production is achieved precisely due to cheap labor. Therefore, the Ukrainian employer has no incentive to introduce the latest digital technologies.

In technologically advanced countries, the digital economy opens up new opportunities for high-income employment. This is a space for the following categories of workers: inventors and manufacturers of digital technologies; workers providing the functionality of digital technologies; employees of the digital economy sectors interacting with digital systems as their appendages (operators); workers who lose their jobs as a result of the implementation of digital systems (Kolesnik, 2018) Of course, it is very difficult to predict what professions will be in demand in the digital economy in $10-15$ years, but they will be associated with information.

According to available forecasts, $51 \%$ of jobs in the European Union will be automated by 2030 . To reduce 
the social costs of this process, the European education system aims to teach the skills that will be required in the context of digital production automation (European Commission...).

And if everything is more or less clear with the future of professionals in the field of high technologies, the question arises: how much will be in demand in the digital economy for representatives of humanitarian specialties? It seems that analysts with the skills to work with large amounts of data related to the legal sphere, for example, digital intellectual property, will be needed in the digital labor market. Considering that digital technologies are already penetrating all humanitarian professions, their representatives have every chance of finding their place in the new reality.

There are already examples of successful cooperation between technical and humanitarian universities, the goal of which is to train a new generation of "humanities" with hard skills and "techies" with soft skills (Tcifrovaia ekonomika...).

The education system that implements distance learning technologies, on the one hand, expands the access of various segments of the population to quality education; on the other hand, the creation of information databases poses a threat to the confidentiality of students and teachers. It should also be borne in mind that the distance learning process is completely dependent on technical means. Poor quality of Internet connection can interrupt the finest lecture and practice. Obtaining an exclusively distance education deprives students and teachers of communicating in an informal student environment, which can be an impetus for new discoveries and inventions. But, as the phrase attributed to Socrates says, "The truth is born in dispute." And even if those who believe that Socrates later spoke about dialogue in this way are right, the meaning in our case does not change. Remote communication limits the possibilities of non-verbal communication, which is known to be indispensable in an informal setting.

Nevertheless, it is indisputable that in the near future online courses will be more and more in demand, which is primarily due to the fact that as a result of the disappearance of a number of professions under the influence of digitalization mentioned above people will face the need to retrain several times throughout life. Therefore, we can conclude that the principle of the educational strategy "Learning throughout life", which has emerged three decades ago due to UNESCO and the Council of Europe, is becoming more relevant.

The use of digital technologies in medicine (telemedicine) has many advantages. This is also access to medical services for the population from remote rural areas. It also saves time for patients and doctors. This is an opportunity for family doctors from the same remote areas to receive urgent advice from specialists on the necessary measures to treat patients and much more.
At the same time, telemedicine cannot solve all the existing problems of patient care.

One of the problems, which are especially important, is that, while distance education services are usually used by young people, there is a large proportion of older people among the recipients of medical services; of these, only a few are digitally literate. According to a recent study of Ukraine's digital divide carried out by the Ministry of Digital Transformation in cooperation with UNDP, East Europe Foundation, the EdEra educational platform and other organizations, only $26 \%$ of the older generation considers it important to acquire digital skills (Podolannia tsyfrovoho rozryvu...). The same study has concluded that for older people, the most in-demand electronic services are utilities, medical and financial services.

Digital literacy is the most important factor without which the development of modern society, e-democracy, e-government, political participation, improvement of anti-corruption tools, e-health, and smart cities is impossible. But no "smart" technology can be useful if people are unable or unwilling to use them. Thus, the problem of people's readiness to digitalize their lives arises. According to the Ministry of Digital Transformation of Ukraine in 2019, 53\% of Ukrainians had digital literacy at a level below average. In 2020, the Ministry launched a national test for digital literacy "Cifrogram” (Mintcifry zapustil natcionalnyj test... ).

It goes without saying that society needs security systems, personal and collective. However, in exchange for security, the state deprives the individual of the confidentiality of personal data. More and more people's lives are under the control of video surveillance systems, in terms of tracking mobile phones. Collecting information about the population is becoming commonplace in many countries. Ukraine is also following this path, although not so quickly due to the lack of technological, administrative and financial resources.

China has especially "succeeded" in this, which is actively implementing the National Program "Creating a Social Credit System" (2014-2020), within the framework of which all residents are monitored online. Their reward or punishment depends on the so-called "social credit" of Chinese residents. At first glance, this program has good intentions: it helps in solving social problems such as crime, homelessness, corruption, violation of various social rules. Amid the coronavirus pandemic, 170 million video cameras in major Chinese cities are helping to track those who violate selfisolation. All this speaks of the contradiction between the desire for security and the problem of violation of human rights and freedoms by the state. Similar systems of total surveillance under the pretext of combating the coronavirus pandemic are being introduced in Russia, Iran, Europe, and the United States. The difference is that in democracies they will be dismantled after the 
pandemic. But as far as countries with non-democratic regimes are concerned, there is a possibility that such systems that violate human rights will continue to be used under various pretexts.

\section{Digitalization as a tool to combat bureaucracy and corruption in welfare state}

As you know, one of the restraining factors of the welfare state is bureaucratization and corruption. Digitalization is recognized worldwide as a tool that can significantly reduce the level of these social phenomena. It has already become axiomatic that the more transparent and open the public administration system, the lower the corruption risks.

The Ukrainian government is also making such anti-corruption attempts. "Speaking about the implementation of digitalization in all areas of the Ukrainian society, the new government means, first of all, electronic document management, digital signatures, open and accessible databases and much more. The main goal is to free Ukrainians from paper bureaucracy, endless queues at government agencies and the need to confirm the saying "you won't go unless you drease", which has already become a tradition for them (Silenko, 2019).

It also seems expedient to use foreign experience in the effective use of digital technologies in Ukraine for interaction between citizens and the state. For example, in South Korea, any citizen has the opportunity to file an online corruption report and track the process of its consideration. The South Korean citizen is confident that his or her statement will not pass by the attention of law enforcement agencies. In Singapore, due to the introduction of IT technologies, the state apparatus was significantly reduced. In public places, citizens can receive electronic services and reference information through special terminals. Citizens use their mobile devices to connect to government social service ports.

How quickly the sphere of social policy will be digitized will determine how long officials will physically influence the process of solving social problems of citizens. Despite the low level of digital literacy of the population and officials, neither one nor the other has doubts about the benefits of digitalization. In favor of the digitalization of the public administration system, including in the social sphere, the following arguments can be made:

- public authorities are becoming more sensitive to the needs of citizens, less costly and hierarchical;

- the obligation to publish government information strengthens government accountability to citizens;

- the work of officials is facilitated, the procedure for their relationship with citizens is improved;

- citizens get the opportunity to receive social services as soon as possible without visiting officials;
- increasing the level of openness and transparency of the decision-making process improves opportunities for combating corruption;

- the introduction of digital technologies into public administration has economic efficiency.

Some scientists, based on the analysis of research results, conclude that officials, introducing information technologies into the activities of their structures, think, first of all, about the personal benefits. And not in order to make life easier for citizens (Solodov, 2008). Perhaps it is but citizens, for whom appealing to government bodies becomes less bureaucratic and more effective, do not care about the motivation of officials.

Indeed, in the context of the introduction of information technologies into public administration, in the so-called e-government, it is no longer so easy for officials to bureaucratize the process of providing citizens with social services.

However, their disinterest in the loss of the monopoly on information and transparency of activities leads to the fact that the traditional bureaucracy is being replaced by a new form of bureaucracy - electronic. According to S. Kabashov, "a characteristic feature of e-bureaucracy, in contrast to the classical one, is creativity, the transition from one management project to another by attracting our expanding networks and constantly updated knowledge to effectively perform management tasks" (Kabashov).

Officials as well as all citizens are given the opportunity to use the benefits of digitalization for their own purposes. Today we can already say that the expectations of those who believed that the bureaucracy in the digital economy would weaken its influence did not come true. Moreover, we can say that, on the contrary, the influence of the bureaucracy, now electronic, has increased. In this regard, one of the most famous American political consultants, D. Morris, wrote that the executive bureaucracy has only one goal to maintain its monopoly (Morris, 2003).

\section{Technologies of the digital economy in the social state of Ukraine}

The digital economy emerges from the traditional economy through the process of digital transformation. According to Iu. Gribanov, "Digital transformation is the introduction of modern digital technologies in business processes of socio-economic systems of all levels" (Gribanov, 2019) We share the opinion of the researcher that this process includes not only the provision of modern equipment and software, but also new approaches to management, corporate culture, external communications, etc. All this is the key to the success of not only the organization as a whole, but also each employee individually. This is understood by Ukrainian business, which is introducing digital technologies into its activities more and more 
intensively. But state organizations and institutions are still far behind. Therefore, on January 17, 2018, the Ukrainian government adopted the Concept of the Development of the Digital Economy and Society of Ukraine for 2018-2020 and approved an action plan for its implementation.

With the arrival of the new Ukrainian government in 2019, a decisive course was taken towards the digitalization of the country, as evidenced by the creation of the Ministry of Digital Transformation of Ukraine (Ministry of Digital Transformation). Ambitious goals for the digitalization of Ukraine until 2024 have been proclaimed: $100 \%$ of public services will be available to citizens and businesses online; $95 \%$ of transport infrastructure, settlements and their social facilities will have access to high-speed Internet; 6 million Ukrainians will be attracted to the digital habits development program; the share of IT in the country's GDP will be $10 \%$ (Ofitsiinyi sait Ministerstva...). However, unfortunately, the website of the Ministry does not have a 4-year step-by-step program that will allow to achieve these goals.

As noted on the website, the Ministry of digital Transformation of Ukraine is working to ensure that the most vulnerable segments of the population receive social services in a quality and timely manner (Ofitsiinyi sait Ministerstva ...).

Today, according to the Ministry, 37\% of hospitals do not have high-quality Internet, which means that there are no technical conditions for the development of telemedicine. Also, the lack of the Internet creates inconvenience for hospital patients. $40 \%$ of Ukrainian schools lack a high-quality Internet connection (Ofitsiinyi sait Ministerstva ...).

One of the first steps on the way to the digital economy was the Internet application "Diia" within the framework of the "State in a Smartphone" project, which has been operating in Ukraine since February 2020. Ukrainians have been able to use government services via the Internet. The masterminds and developers of the project plan that in 3-5 years all public services will be digitized. The first state services in digital format, which have been received by the citizens of Ukraine, are an electronic driver's license and a vehicle registration certificate. For this, 6 million driver's licenses have been digitized in a short time.

It should be noted that these are not the first online services for Ukrainian citizens. For several years now, an e-government system has been introduced in the country, the purpose of which is to minimize bureaucracy and corruption in the field of public administration. By the time Diia Internet application was introduced, 125 different electronic services were already available for the population, including the registration of housing subsidies.

To implement the reform of social protection and the protection of children's rights in the process of decentralization, the Ministry of Digital Transformation of Ukraine aims to introduce those digital technologies that will bring social support and social protection closer to people. Community representatives will have the opportunity to digitally transmit to the relevant executive authorities all appeals from citizens and organizations on social issues. Administrative Service Centers (ASC) will be created in each territorial community. Local governments will be able to connect to the digital platform "Social Community" free of charge. Convenient and accessible Internet services will be provided to citizens in need of social support. According to Liudmyla Rabchynska, Deputy Minister of Digital Transformation of Ukraine, "Starting from 2021, all ASCs will accept applications and documents for assigning social support. This step will significantly increase the effectiveness of social protection of the population. In addition, the Ministry of Digital Development plans to introduce and provide electronic information interaction in the provision of administrative services of a social nature, including through the Administrative Service Centers" (Ofitsiinyi sait Ministerstva ...).

On August 5, the Ukrainian government approved the State Strategy for Regional Development for 2027. Much attention in the document is paid to digital transformation. The strategy plans to implement 60 digital transformation tasks. Among them, it is especially important to increase the digital literacy of the population, ensure uninterrupted access to high-speed Internet for all settlements (primarily, rural and small towns); receiving electronic services via a smartphone; introduction of electronic document management; development of e-democracy mechanisms, etc. The document also provides for the introduction of a system for electronic receipt of documents and the provision of the possibility of applying for social services through online services and electronic queuing systems. In the field of education, it is planned to create an electronic educational system, introduce modern curricula at all levels of education for the effective formation of modern digital skills and the introduction of new professions. (Tsyfrovizatsiia - odyn z holovnykh prioritetiv...).

In October 2020, the Cabinet of Ministers of Ukraine adopted a decree "On Approval of the Strategy for Digital Transformation of the Social Sphere". The goal of a comprehensive digital transformation of the social sphere is "to ensure European standards for the provision of services, strengthen financial stability, increase the transparency of the social sphere, and optimize its administrative costs." In particular, the provision of social services through outsourcing, automated monitoring and control of all financial flows in the social sphere will allow to optimize administrative costs. It is assumed that the measures taken will make it easier for the population, including for its vulnerable groups, access to social services (Kabmin zatverdyv...). 
However, we have to state that the level of Ukraine's readiness for digitalization is still low. Experts emphasize the relevance of the issue of the readiness of the Ukrainian market to purchase IT products, noting that "the need for digital products in Ukraine, in particular software, is at a low level of $15-16 \%$, while in the world market it is about 60\%" (Prezentatsiia analitychnoho doslidzhennia...).

\section{Conclusion}

An analysis of the degree of development of the problem showed that the issues of the digital economy are mainly in the sphere of interests of scientistseconomists, while the socio-political aspects of the digital economy are not yet fully investigated. In particular, there are still no comprehensive studies of the impact of the digital economy on the development of the welfare state in Ukraine. The hypothesis of the study, namely that the digital economy improves the quality and living conditions of citizens in a welfare state, was partially confirmed. However, it became clear that in addition to positive, the digital economy has negative consequences for people. For example, the digital economy improves the ability to solve many social problems, but at the same time creates new problems. For example, it creates new jobs, new professions, as a result of which workers in traditional professions become unclaimed. The digital economy not only solves and creates problems, but also exposes them. So, it clearly outlines the problem of social inequality in Ukraine.

In addition, it should be recognized that there will be no digitalization and social policy unless sound investments. Such a state is doomed to catastrophically lag behind economically developed countries.

The use of digital technologies in the social sphere does not eradicate bureaucracy and corruption, but helps to reduce their level. Processes for providing public services, conducting public procurement and managing budget funds are becoming more open, transparent, and therefore more honest.

Undoubtedly, the digitalization of public social services makes life easier for people, but only if they are prepared for this process. Digital illiteracy of the population, characteristic of countries lagging behind in technological development, including Ukraine, is an obstacle to the introduction of digitalization into the social sphere. At the same time, the state is not ready for the active introduction of digital technologies into the system of social policy due to the lack of necessary resources. No amount of digitalization will improve people's lives unless the state has funds for social policy. Some measures are being taken in this direction. In particular, technologies are being introduced to improve the digital literacy of the population, to ensure uninterrupted access to high-speed Internet for all settlements (primarily, rural and small towns); receiving electronic services via a smartphone; introduction of electronic document management; development of e-democracy mechanisms. It is also planned to introduce a system of electronic receipt of documents and ensure the possibility of applying for social services through online services and electronic queue systems, etc. The digital future is not far off and the welfare state must be ready for it.

\section{References:}

Abeliansky, A. L., \& Hilbert, M. (2017). Digital technology and international trade: Is it the quantity of subscriptions or the quality of data speed that matters? Telecommunications Policy, no. 41(1).

Silenko, A. O. (2000). Sotsialna derzhava: evoliuciia ideyi, sutnist ta perspektyvy stanovlennia v suchasnii Ukraini. Avtoreferat dysertatsii doktora politychnykh nauk. Spetsialnist 23.00 .02 - politychni instytuty ta protsesy. Kyiv. Available at: www.irbis-nbuv.gov.ua (accessed 10 November 2020).

Khoma, N. M. (2012). Modeli sotsialnoi derzhavy: svitovyi ta ukrainskyi dosvid: monohrafiia. Kyiv: Yurydychna dumka. (in Ukrainian)

Shulzhenko, F. P. (2007). Sotsialno-pravova derzhava v Ukraini: problem stanovlennia ta modernizatsii. Kyiv: KNEU. (in Ukrainian)

Kupchishina, E. V. (2018). Evoliutciia kontceptcii tcifrovoi ekonomiki kak fenomena neoekonomiki. Gosudarstvennoe upravlenie, no. 68.

Maslov, A. O. (2012). Informatsiina ekonomika: stanovlennia, struktura ta teoretychne osmyslennia: monohrafia. Kyiv: Agrar Media Gr. (in Ukrainian)

Veretiuk, S. M., \& Pilinskyi, V. V. (2016). Vyznachennia prioritetnykh napriamkiv rozvytku tsyfrovoi ekonomiky v Ukraini. Naukovi zapysky Ukrainskoho naukovo-doslidnoho instytutu zviazku, no. 2.

Liashenko, V. I., \& Vyshnevskyi, O. S. (2018). Tsyfrova modernizatsiia ekonomiky Ukrainy yak mozhlyvist proryvnoho rozvytku: monohrafiia. Kyiv: NAN Ukrainy, In-t ekonomiky prom-ti. (in Ukrainian)

Matveichuk, L. O. (2018). Tsyfrova ekonomika: teoretychni aspekty. Visnyk Zaporizkoho natsionalnoho universytetu, no. 4(40).

Gribanov, Iu. I. (2019). Cifrovaya transformaciya socialno-ekonomicheskih sistem na osnove razvitiya instituta servisnoj integracii. Dissertaciya doktora ekonomicheskih nauk. Specalnost: 08.00.05 - Ekonomika i upravlenie narodnym hozyajstvom (ekonomika, organizaciya i upravlenie predpriyatiyami, otraslyami, kompleksami - sfera uslug). Sankt-Peterburg. (in Russian) 
Peshchannikova, E. N. (2019). Tcifrovaia transformatciia sotcialno-ekonomicheskikh sistem na osnove razvitiia instituta servisnoi integratcii. Dissertatciia doktora ekonomicheskikh nauk. Spetcialnost: 08.00.05 - Ekonomika i upravlenie narodnym khoziaistvom (ekonomika, organizatciia i upravlenie predpriiatiiami, otrasliami, kompleksami - sfera uslug). Moskva. (in Russian)

Vilken, V. V. (2020). Upravlenie regionalnym razvitiem v usloviiakh tcifrovoi ekonomiki. Avtoref. dissertatcii kandidata ekonomicheskikh nauk. Spetcialnost 08.00.05 - Ekonomika i upravlenie narodnykm khoziaistvom (regionalnaia ekonomika). Sankt-Peterburg. (in Russian)

G20 Programma po razvitiiu i sotrudnichestvu v sfere tcifrovoi ekonomiki (Itogovyi dokument - 2016). Available at: http://www.eurasiancommission.org/ru/act/dmi/workgroup/materials (accessed 29 October 2020).

Konferentciia G20 na urovne Ministrov po tcifrovoi ekonomike. Diusseldorf 6-7 aprelia 2017. Deklaratciia Ministrov po tcifrovoi ekonomike. Available at: www.eurasiancommission.org (accessed 29 October 2020).

Karcheva, H. T., Ohorodnia, D. V., \& Openko, V.A. (2017). Tsyfrova ekonomika ta yii vplyv na rozvytok natsionalnoi ta mizhnarodnoi ekonomiky. Finansovyi prostir, no. 3(27).

Romanova, N. V. (2020). Tcifrovizatciia uslug v sotcialnoi sfere: problemy i perspektivy. Bulletin USPTU. Science, education, economy. Series economy, no. 1(31).

Dvi storony tsyfrovykh tekhnolohii: "tsyfrova dyktatura" abo zberezhennia stiikosti. Available at: https: / / razumkov.org.ua/statti/dvi-storony-tsyfrovykh-tekhnologii-tsyfrova-dyktatura-abo-zberezhenniastiikosti (accessed 29 October 2020).

Konovalova, H., \& Svetlevskaia, A. Professii budushchego v Ukraine: nanovrachi, menedzhery avatarov i sitifermery. Available at: https://economics.segodnya.ua/economics/enews/professii-budushchego-v-ukrainenanovrachi-menedzhery-avatarov-i-siti-fermery-872726.html (accessed 29 October 2020).

Kolesnik, A. P. (2018). Socialnye sistemy v cifrovoj ekonomike. Strategii biznesa, no. 1(45). Available at: https://www.strategybusiness.ru/jour/article/view/395 (accessed 29 October 2020).

European Commission. E-skills for Europe: Towards 2017 and beyond. European E-Skills Forum Synthesis Report, Brussels. 2018.

Tcifrovaia ekonomika: kak meniaiutsia obrazovanie i rynok truda. Available at: https://vc.ru/hr/109476-cifrovayaekonomika-kak-menyayutsya-obrazovanie-i-rynok-truda (accessed 29 October 2020).

Podolannia tsyfrovoho rozryvu v Ukraini: liudynotsentrychnyi pidkhid. Available at: https://www.ua.undp.org/ content/ukraine/uk/home/blog/2020/bridging-the-digital-divide-in-ukraine--a-human-centric-approach.html (accessed 13 November 2020).

Mintcifry zapustil natcionalnyi test na tcirovuiu gramotnost "Tcifrogram". Available at: https://itc.ua/news/ minczifry-zapustil-naczionalnyj-test-na-czifrovuyu-gramotnost-czifrogram-posle-sdachi-mozhno-poluchitsertifikat-s-urovnem-i-ballami/ (accessed 29 October 2020).

Silenko, A. A. (2019). Digitalization In The Fight Against Corruption In Ukraine. Man, society, politics: topical challenges of the modernity: collective monograph / N. M. Baklanova, O. V. Diachenko, L. M. Dunayeva, N. P. Hedikova, etc. Lviv-Toruń: Liha-Pres. doi: 10.36059/978-966-397-183-4/147-159

Solodov, V. (2008). Elektronnaia biurokratiia: postbiurokratiia ili sverkhbiurokratiia. Vlast, no. 4.

Kabashov, C. Elektronnaia biurokratiia: k postanovke problemy. Available at: https://www.bagsurb.ru/about/ journal/Part\%202_articles.pdf

Morris, D. (2003). Novyi gosudar. Novaia versiia Makiavelli dlia XX veka. Gruppa Kompanii “Nikkolo M".

Ofitsiinyi sait Ministerstva ta Komiteta tsyfrovoi transformatsii. Available at: https://thedigital.gov.ua/ministry (accessed 27 October 2020).

Tsyfrovizatsiia - odyn $\mathrm{z}$ holovnykh prioritetiv derzhstratehii rehionalnoho rozvytku. Available at: https: / / www.auc.org.ua/novyna/cyfrovizaciya-odyn-z-golovnyh-priorytetiv-derzhstrategiyi-regionalnogorozvytku (accessed 29 October 2020).

Kabmin zatverdyv yevropeiski standarty nadannia sorsialnykh posluh. Available at: https://www.unn.com.ua/uk/ news/1899817-kabmin-zatverdiv-yevropeyski-standarti-nadannya-sotsialnikh-poslug (accessed 29 October 2020).

Prezentatsiia analitychnoho doslidzhennia "Tsyfrova ekonomika: trendy, ryzyky ta sotsialni determinanty". Available at: https://www.ukrinform.ua/rubric-presshall/3121760-prezentacia-analiticnogo-doslidzenna-cifrovaekonomika-trendi-riziki-ta-socialni-determinanti.html (accessed 26 November 2020). 